\title{
A homolog of the RPS2 disease resistance gene is constitutively expressed in Brassica oleracea
}

\author{
Celia C. Malvas, Maeli Melotto, Daniela Truffi and Luis E.A. Camargo \\ Universidade de São Paulo, ESALQ, Departamento de Patologia de Plantas, Piracicaba, SP, Brazil.
}

\begin{abstract}
In this study, we identified disease resistance gene homologs in Brassica oleracea and assessed their expression in lines resistant and susceptible to Xanthomonas campestris pv. campestris (Xcc). Two DNA fragments of approximately $2.5 \mathrm{~kb}$ (BI-16/RPS2 and Lc201/RPS2) were amplified by PCR from two Brassica lines using primers based on an RPS2 homologous sequence previously described in the Brassica oleracea ecotype B117. The sequences of these fragments shared high similarity (95-98\%) with RPS2 homologs from various Brassica species. The digestion of these fragments with restriction enzymes revealed polymorphisms at the $\mathrm{Xba}$ I restriction sites. The length polymorphisms were used as a co-dominant marker in an $\mathrm{F}_{2}$ population developed to segregate for resistance to Xcc, the causal agent of black rot. Linkage analysis showed no significant association between the marker and quantitative trait loci for black rot. RT-PCR with specific primers yielded an expected 453 bp fragment that corresponded to the RPS2 homologs in both resistant and susceptible lines inoculated with the pathogen, as well as in non-inoculated control plants. These results suggest that these homologs are constitutively expressed in $B$. oleracea.
\end{abstract}

Key words: Xanthomonas campestris pv. campestris, disease resistance gene homolog, black rot.

Received: January 1, 2003; Accepted: August 15, 2003.

\section{Introduction}

In recent years, numerous resistance genes $(\mathrm{R})$ have been cloned and their sequences have revealed common motifs (Martin, 1999), including leucine rich repeats (LRRs) and nucleotide binding sites (NBS) (Jones, 2001; Staskawicz, 2001). NBS-LRRs resistance proteins serve to recognize avirulence $(A v r)$ gene products from extracellular pathogens, thereby initiating a cascade defense response (Schaal and Olsen, 2000; Dangl and Jones, 2001; Bergelson et al., 2001). An interaction between $\mathrm{R}$ and $A v r$ genes was demonstrated when a mutation within the C-terminal portion of an Avr gene led to the loss of recognition (Axtel et al., 2001), indicating a role for LRR domains in this phenomenon (Banerjee et al., 2001).

The nucleotide sequences of these conserved domains have been used to generate primers and to amplify homologous disease resistance genes in correlate and distant species. In several cases, these homologs are linked to resistance genes (Leister et al., 1998; Collins et al., 1998; Shen et al., 1998; Speulman et al., 1998; Aarts et al., 1998; Melotto and Kelly, 2001).

Send correspondence to L.E.A. Camargo. Caixa Posta 9, 13418-900 Piracicaba, SP, Brazil. E-mail: leacamar@ carpa.ciagri. usp.br.
The RPS2 gene of Arabidopsis thaliana confers resistance to Pseudomonas syringae pv. tomato (Bent et al., 1994; Mindrinos et al., 1994). This gene, which is located on chromosome 4, encodes a protein with 909 amino acids and contains NBS and LRRs domains, as well as a leucine zipper (LZ). Recently, Banerjee et al. (2001) showed that more than one gene in Arabidopsis is associated with the defense response to $P$. syringae. A high level of nucleotide polymorphism at the 3' end of the RPS2 gene has also been demonstrated (Caicedo et al., 1999).

A homolog of the RPS2 gene in Brassica oleracea (Wroblewski et al., 2000) shares $83 \%$ sequence identity with the nucleotide sequence of the $A$. thaliana RPS 2 gene and $80 \%$ similarity to its predicted aminoacid sequence. Southern blot analysis revealed a single copy and no introns, as in A. thaliana. Nucleotide polymorphisms of this homolog found in members of the tribe Brassiceae have been compared in an attempt to determine their evolutionary history. In this study, we examined the expression of a homolog of the RPS2 gene in two B. oleracea lines and assessed the linkage between this homolog and quantitative trai loci (QTL) controlling resistance to Xanthomonas campestris pv. campestris (Xcc), the causal agent of black rot. Two fragments (BI-16/RPS2 and Lc201/RPS2) homologous to the RPS2 gene were amplified by PCR and were 
found to be constitutively expressed. There was no linkage to resistance QTLs.

\section{Material and Methods}

\section{Plant material and inoculation procedure}

The cabbage inbred line Badger Inbred-16 (BI-16), resistant to Xcc (Camargo et al., 1995) and the susceptible 'fast cycling' inbred line Lc201 (Williams and Hill, 1986) were used in this study. An $\mathrm{F}_{2}$ population derived from the cross BI-16 x Lc201 previously screened for black rot resistance (Malvas et al., 1999) was used in a segregation analysis to study the linkage relationships between disease resistance homologs and quantitative trait loci (QTL) controlling resistance to $X$. campestris pv.campestris.

Parental lines were inoculated with the isolate PHW 1205 of $X$. c. pv. campestris by clipping the leaf tip and rubbing a cotton swab saturated with bacterial suspension over the wounded site as previously described (Camargo et al., 1995). Control plants were inoculated with water. Inoculated plants were analyzed for their phenotypic reaction to the pathogen seven days after inoculation.

\section{Cloning and sequencing of the RPS2 homologs BI-16/RPS2 and Lc201/RPS2}

A pair of primers was designed based on the partial sequence of a published $B$. oleracea genomic fragment (GenBank accession number AF180355) homologous to the RPS2 gene (Wroblewski et al., 2000) and used to amplify homologous fragments from our lines by PCR.

The PCR mixtures contained $150 \mathrm{ng}$ of genomic DNA, $0.2 \mathrm{mM}$ dNTPs (Life Technologies, Rockeville, MD), $0.25 \mu \mathrm{M}$ of each primer, $4.0 \mathrm{mM} \mathrm{MgCl} 2,1 \mathrm{x}$ reaction buffer and $5 \mathrm{U}$ of high fidelity Taq DNA polymerase (Life Technologies, Rockeville, MD) in a final volume of $50 \mu \mathrm{L}$. The reactions were run in a PTC100 thermal cycler (MJ Research) with the following conditions: one cycle of $5 \mathrm{~min}$ at $94{ }^{\circ} \mathrm{C}$, followed by 35 cycles of $1 \mathrm{~min}$ at $94^{\circ} \mathrm{C}, 2 \mathrm{~min}$ at $65^{\circ} \mathrm{C}$ and $5 \mathrm{~min}$ at $72^{\circ} \mathrm{C}$, and a final extension of $15 \mathrm{~min}$ at $72{ }^{\circ} \mathrm{C}$. The PCR products were resolved on $1 \%$ agarose gels in $0.5 \mathrm{x}$ TBE buffer.

The PCR fragments were sonicated for $30 \mathrm{~s}$ at $750 \mathrm{~W}$-s in an ultrasonic homogenizer (Cole Parmer), and fragments 500 to $750 \mathrm{bp}$ in size were excised from the agarose gel and purified with a Sephaglas Band prep kit (Amersham Pharmacia Biotech, Piscataway, NJ). Sonicated fragments were cloned into pUC18 using a Sure Clone kit (Amersham Pharmacia Biotech). Plasmid DNA was purified according to Sambrook et al. (1989) and used as the template in sequencing reactions with a Ready Reaction Dyedeoxy Terminator Cycle sequencing kit (Applied Biosystems, Foster City, CA). The DNA sequences were obtained using an ABI 377 DNA sequencer (Applied Biosystems, Foster City, CA) and evaluated using internet-based facilities such as BLAST (http://www.ncbi. nlm.nih.gov) (Altschul et al., 1997) and the computer program Sequencher 3.0 (Gene Codes Corporation, Ann Arbor, MI).

\section{Analysis of restriction fragment length polymorphisms between BI-16/RPS2 and LC201/RPS2}

DNA sequences were analyzed for their restriction patterns by electronic digestion with the software Sequencher 3.0. The restriction enzymes Pst I, EcoR I, $E c o \mathrm{R} \mathrm{V}$, and $X b a$ I were used to digest the DNA fragments amplified from the parental lines BI-16 and Lc201 as well as from an $F_{1}$ individual in order to confirm the length polymorphisms. Enzymes that revealed polymorphisms were then used to digest the RPS2 homologous fragment amplified from the $F_{2}$ population. The digestion reaction contained $1 \mathrm{x}$ buffer, $10 \mathrm{U}$ of restriction enzyme and $8 \mu \mathrm{L}$ of PCR mix which was incubated for $6 \mathrm{~h}$ at $37^{\circ} \mathrm{C}$. The restriction fragments were visualized in $0.8 \%$ agarose gels.

\section{RT-PCR}

Twenty-four hours after inoculation, 100 milligrams of leaf tissue were harvested, frozen with liquid nitrogen and stored at $-80^{\circ} \mathrm{C}$ until mRNA isolation. mRNA was isolated with an Oligotex Direct mRNA midi kit (Qiagen $\mathrm{GmbH}$, Hilden, Germany) and quantified spectrophotometrically. cDNA was synthesized from approximately $3 \mu \mathrm{g}$ of mRNA using the Superscript One Step RT-PCR kit with Platinum Taq (Life Technologies Inc. Galthersburg) and amplified with specific primers designed between nucleotides 580 and 1100 of the BI-16/RPS2 homolog in order to produce a fragment of approximately $500 \mathrm{bp}$. DNA contamination of RNA samples was monitored with a negative control by using mRNA as template in the reactions. The assays were run using one cycle of $2 \mathrm{~min}$ at $93^{\circ} \mathrm{C}$, followed by 35 cycles of $45 \mathrm{~s}$ at $93{ }^{\circ} \mathrm{C}, 45 \mathrm{~s}$ at $51^{\circ} \mathrm{C}$ and $1 \mathrm{~min}$ at $72{ }^{\circ} \mathrm{C}$, and a final extension of $10 \mathrm{~min}$ at $72^{\circ} \mathrm{C}$, after which the PCR products were separated in $1 \%$ agarose gels with $0.5 x$ TBE buffer.

\section{Results}

A set of primers based on the RPS2 homologous sequence previously described in B. oleracea ecotype B117 (Wroblewski et al., 2000) was used to amplify a fragment of approximately $2.5 \mathrm{~kb}$ from our parental lines. The forward and reverse primer sequences were 5'-GCAGGACATTAAGACTGATCTTAAGC-3' and 5'-GCTGGCAAGTTTGGCTGGACCCTTTCC-3', respectively. PCR using these primers amplified a single 2.5 $\mathrm{kb}$ DNA fragment in B1-16 and Lc201 (not shown). Sequencing of the clone amplified fragments revealed 95\% sequence identity between BI-16/RPS2 and Lc201/RPS2 was $95 \%$. Comparison of the sequences identified 112 base 
substitutions ( $4.3 \%$ of bases) and 18 indels (insertions/deletions; $0.7 \%$ of bases).

The BI-16/RPS2 and Lc201/RPS2 sequences were compared with other sequences deposited in the GenBank database using the BLASTN search software (Altschul et al., 1997). The alignment obtained at the nucleotide level revealed a high similarity to RPS2 homologs previously described in Brassica species such as B. montana (AF180358; $98 \%$ identity, $0 \%$ gap), B. oleracea ecotype B117 (AF180357; 98\% identity, $0 \%$ gap) and B. rapa (AF180359; 95\% identity, $0 \%$ gap). The 5 ' end of the DNA sequence corresponding to the predicted LRR domain showed $100 \%$ similarity to the RPS2 homolog from ecotype B117.

The BI16/RPS2 fragment amplified from the resistant line showed an open reading frame (ORF) of 2,506 nucleotides with one frame shift at the 5' end. The Lc201/RPS2 fragment amplified from the susceptible line showed stop codons, although three ORFs of $875 \mathrm{bp}, 791 \mathrm{bp}$, and 1,452 $\mathrm{bp}$ were identified. In both sequences, three domains were identified and arranged in the following order leucine zipper (LZ), nucleotide binding site (NBS), and leucine rich repeat (LRR).

Alignment of the derived amino acid sequences of the two cloned homologs showed high similarity (E value of $0.0)$ to the RPS2 protein described in Arabidopsis and to the RPS2 homolog in Brassica species (Figure 1), as well as to other resistance gene sequences such as RPR 1 from Oryza sativa (gi $\mid$ 4519936) and $R G C 2 J$ from garden lettuce (gi|7489352).

To detect the expression of RPS 2 homologs in response to inoculation with Xcc, mRNA extracted from BI-16 and Lc201 leaves $24 \mathrm{~h}$ after inoculation was transcribed and cDNA was obtained with primers designed to amplify a 453-bp segment internal to the BI-16/RPS2 fragment. PCR analysis confirmed the presence of the fragment in both the resistant and susceptible lines (Figure 2). This result suggests that these homologs are constitutively expressed in $B$. oleracea. The sequenced cDNA fragment from the resistant line aligned with the genomic sequence between nucleotides 479 and 931 (NBS domain) and showed 14 nucleotide substitutions and two indels $(97 \%$ identity).

Alignment of the BI-16/RPS2 cDNA sequence with the Arabidopsis genome showed $87 \%$ identity with the BAC clone F20B18 (emb|AL049483.1) located on the chromosome 4 of Arabidopsis that harbors the RPS2 locus. In addition, a cluster of Arabidopsis EST clones has been mapped to the same location, indicating that this region is expressed as mRNA. The BI-16/RPS2 cDNA also partially aligned with one of the Arabidopsis EST clones (gi $1217460 ; 90 \%$ identity).

Of the four restriction enzymes tested, only $X b a$ I detected polymorphism between BI-16 and Lc201. There were three $X b a$ I restriction sites in the BI-16/RPS2 frag- ment and two in Lc201/RPS2 (Figure 3). This RFLP was used as a co-dominant marker in an $\mathrm{F}_{2}$ population (91 individuals) and segregated to resistance to Xcc. A linkage analysis of the resistance phenotypes of $\mathrm{F}_{2}$ plants and their marker genotypes indicated no significant association $(\mathrm{F}=$ $0.21, \mathrm{p}<0.01$ ) between the marker and resistance QTLs previously mapped in this population (Malvas et al., 1999; Camargo et al., 1995).

\section{Discussion}

In this study, we identified two disease resistance gene homologs, BI-16/RPS2 and Lc201/RPS2, and demonstrated their constitutive expression in B. oleracea lines. PCR amplification using specific primers amplified a single $2.5 \mathrm{~kb}$ fragment in Brassica lines and the DNA sequences of the fragments showed similarity to NBS-LRR domains present in some previously cloned resistance genes, including the RPS2 gene of Arabidopsis. The 5\% sequence divergence between BI16/RPS2 and Lc201/RPS2 indicates that these fragments could possibly represent different alleles.

The lack of co-segregation between these fragments and QTLs for resistance to Xcc does not preclude them from being part of a resistance locus or part of a gene that confers resistance to another pathogen. The RFLP that distinguished the two fragments may be used as a marker to detect resistance genes in other segregating populations. Resistance gene homologs are not always closely associated with resistance phenotype and may be only loosely linked to a known resistance locus (Melotto and Kelly, 2001). Four other disease resistance gene homologs have been reported not to be linked to any resistance QTLs previously mapped in B. oleracea, probably because of the small number of resistance genes identified in this species (Vicente and King, 2001). Similarly, in maize, the $h t 2$, $h t n 1, h m 2$ and $m s v 1$ disease resistance gene homologs were found unlinked to any known resistance gene (Collins et al., 1998). However, even in these cases, it is possible that linkage does exist, but between the homologs and another as yet undescribed $\mathrm{R}$ gene.

RT-PCR detected BI-16/RPS2 and Lc201/RPS2 cDNAs in non-inoculated tissue. This may indicate that these homologs are involved in resistance mechanisms since the vast majority of R genes are also constitutively expressed. The presence of the LRR and NBS domains further indicates that these homologs may have a recognition function similar to that of $\mathrm{R}$ genes.

The differences between the cDNA and the genomic sequences of BI-16/RPS2 suggest the occurrence of two copies of this gene, which may exist in a cluster. An extra copy of the RPS2 homolog in Brassica has been reported by Wroblewski et al. (2000). It is also possible that the enzymes used to digest the fragment amplified from the genomic DNA cleaved the two copies at the same position, thereby generating fragments that co-migrated in agarose 
gels. Gene duplication and the formation of clusters is common in $\mathrm{R}$ genes. The RPP8 gene from Arabidopsis, for in- stance, is present as a single copy in the Col- 0 accession but as two copies in the Ler accession (Dangl and Jones, 2001).

\begin{tabular}{|c|}
\hline $\begin{array}{l}\text { BI-16/RPS2 } \\
\text { B117 } \\
\text { LC201/RPS2 } \\
\text { RPS2 }\end{array}$ \\
\hline $\begin{array}{l}\text { BI-16/RPS2 } \\
\text { B117 } \\
\text { Lc201/RPS2 } \\
\text { RPS2 }\end{array}$ \\
\hline $\begin{array}{l}\text { BI }-16 / \text { RPS } \\
\text { B117 } \\
\text { LC201/R2 } \\
\text { RPS2 }\end{array}$ \\
\hline $\begin{array}{l}\text { BI-16/RPS } \\
\text { B117 } \\
\text { LC201/RPS } \\
\text { RPS2 }\end{array}$ \\
\hline $\begin{array}{l}\text { BI-16/RPS2 } \\
\text { B117 } \\
\text { LC201/RPS } \\
\text { RPS2 }\end{array}$ \\
\hline $\begin{array}{l}\text { BI-16/RPS2 } \\
\text { B117 } \\
\text { Lc201/RPS2 } \\
\text { RPS2 }\end{array}$ \\
\hline $\begin{array}{l}\text { BI }-16 / \text { RPS2 } \\
\text { B117 } \\
\text { Lc201/RPS2 } \\
\text { RPS2 }\end{array}$ \\
\hline $\begin{array}{l}\text { BI-16/RPS2 } \\
\text { B117 } \\
\text { LC201/RPS2 } \\
\text { RPS2 }\end{array}$ \\
\hline $\begin{array}{l}\text { BI-16/RPS2 } \\
\text { B117 } \\
\text { LC201/RPS2 } \\
\text { RPS2 }\end{array}$ \\
\hline $\begin{array}{l}\text { BI-16/RPS2 } \\
\text { B117 } \\
\text { Lc201/RPS2 } \\
\text { RPS2 }\end{array}$ \\
\hline $\begin{array}{l}\text { BI-16/RPS2 } \\
\text { B117 } \\
\text { LC201/RPS2 } \\
\text { RPS2 }\end{array}$ \\
\hline $\begin{array}{l}\text { BI-16/RPS2 } \\
\text { B117 } \\
\text { Lc201/RPS2 } \\
\text { RPS2 }\end{array}$ \\
\hline $\begin{array}{l}\text { BI }-16 / \text { RPS2 } \\
\text { B117 } \\
\text { Lc201/RPS2 } \\
\text { RPS2 }\end{array}$ \\
\hline $\begin{array}{l}\text { BI-16/RPS2 } \\
\text { B117 } \\
\text { Lc201/RPS2 } \\
\text { RPS2 }\end{array}$ \\
\hline $\begin{array}{l}\text { BI }-16 / \text { RPS2 } \\
\text { B117 } \\
\text { Lc201/RPS2 } \\
\text { RPS2 }\end{array}$ \\
\hline
\end{tabular}

MDCISSLVVGLAQALCESMNMAERRAGHKTDLKQAISDLETATGELKAIRDDLNLRIQRD 60 MPISSLIVGCAQVLCESMNMERRG-HKTDLRQAITLETATGELKAIRDDLNRRIQRD 26 MDEISSLIVGCAQVLCESMNMAERRG-HKTDLRQAITDLETAIGDLKAIRDDLTLRIQQD 59

NIEGRSCTNRAREWLSAVQAAEVRTESILARFMRREQRKMMQRRCLRCLGCASYKLSKK- 85 NLEGRSCTNRAREWLSAVOAAEVRTESILARFMRREOKKMMORRCLSCLGCAEYKLSKK- 119 NREGRSCTNRAREWLSAVOAAEVRTE-IRARFMRREOKKMMORRCLSCG-CAEYKLSKKG 84 GLEGRSCSNRAREWLSAVQVTETKTALLLVRERRREQRTRMRRRYLSCFGCADYKLCKK- 118

----VLGSLKSINQLRQRSLD-IQTDGGLIQETCTKIPTNLSIGITTMMEQVWELFSQE 139 ----DLGSIKSTNELRORSED-TOTDGGITOETCTKI PTKSVVGTTTMMEOVWEITSEE 173 FGARRVLGSLKSMNELKTTALEDIQTDGGLIEETCTKIPTKSVVGIT-------ELLSEE 137 ----VSAILKS I GELRERSEA-IKTDGGSIQVTCREIPIKSVVGNTTMMEQVLEFLSEE 172

EERGI I GVYGPGGVGKTTLMOSI HNELITKGHQYDVLIWVTMSRQFGECTIQQAVGARLG 199 EERGI I GVYGPGGVGKTTLMQSINNELITKGHQYDVLIWVTMSREFGECTIQRAVGARLG 233 EERGIVGVYGPGGVGKTTLMOSMNNEIMTKGHOYDVLIWVAMSREFGECTIORAVGARLG 197 EERGI IGVYGPGGVGKTTLMQSINNELITKGHQYDVLIWVQMSREFGECTIQQAVGARLG 232

LSWDQKETGEGRAFRIYRALKQRRELLLLYHVWEEIDEQKTGVPRPHRENKCKIMETTR- 258 ISWDEKETGEGRAFR YRALKORRELLLLDDVWEEIDEEKTGVPRPDRENKCKIMETTRF 293 LSWDEKETGEGRALRIYRALKQRRELLLLDDVWKEIDEEKTGVPRPDRENKCKIMLTTRS 257 LSWDEKETGENRALKIYRALRQKRELLLLDDVWEEIDLEKTGVPRPDRENKCKVMETTRS 292

-VTLCSNIGAECKLRVEFLEKOHAWELFCGKVGRRDLLESPLIRRHAENIVTKCGGLPLA 317 -LALCSNIGAECKLRVEELEKQHAWEFECGKVGRRDELESPLIRRHAENIVTKCGGLPLA 352 SLALCSNIGAECKLRVEFLEKQHAWELECGKVGRRGLLESPILKGRGDGIVAKCGGLPLA 317 - IALCNNMGAEYKLRVEELEKKHAWELFCSKVWRKDLLESSSIRRLAEIIVSKCGGLPLA 351

LITLGGAMAHRETEEEWIHANEVLNRFPAEMKGMDYVEALLKFSYDNL--ESDLLRTCFL 375 LITLGGAMAHRETEEEWIHANEVLNRFPAEMKGMDYVFALLKFSYDNL--ESDLLRTCEL 410 LMTLGGAMAHRETEEEWIHANEVLNREPAEMKGMDYVEA-LKESYDNLERESDPLRTCEL 376 LITLGGAMAHRETEEEWIHASEVLTRFPAEMKGMNYVFALLKFSYDNL--ESDLLRSCEL 409

YCALEPEDHSIEIEOLVEYWVGEGELISSHGVNTIYOGYFLVGDLKAACLLETGDEKTOV 435 YCALFPEDHSIEIEQLVEYWVGEGFLISSHGVNT IYQGYFLVGDLKAACLVETGDEKTQV 470 YCALFPENHSIEIEQLVEYWVGEGELISSHGVNT IYQGYELVGDLKAACLLETGDEKTQV 436 YCALEPEEHSIEIEQLVEYWVGEGELTSSHGVNTIYKGYFLIGDLKAACLLETGDEKTQV 469

KMHNVVRSFALWMASEQGTYKELILVEPSMGLTGAPKTERWRHTLVISLLDNRLQMLPEN 495 KMHNVVRSFALWMASEQGTYKELILVEPSMGLTEAPKTERWRHTLVISLLDNRLQMLPEN 530 KMHNVVRSEALWMASEQGTDKELILVEPSMGLTEAPKTERWRHTLVISLLDNRLOMLPEN 496 KMHNVVRSFALWMASEQGTYKELILVEPSMGHTEAPKAENWRQALVISLLDNRIQTLPEK 529

PICPNLTTLLLQQNSSLKKIPANEFMYMPVLRVLDLSFTSITEIPLSIKYLVELYHLALS 555 PICPNLTTLLLOONSSLKKI PANFFMYMPVLRVLDLSETSITEIPLSIKYLVELYHLALS 590 PICPNLTTLLLQRNSSLKKIPTNEFMYMPVLRVLDLSETSITEIPLSIKYLVELYRLALS 556 LICPKLTTLMLQQNSSLKKIPTGFFMHMPVLRVLDLSETSITEIPLSIKYLVELYHLSMS 589

GTKISVLPOELRNLRMLKHLDLORTOFLOTIPRDAICWLSKL-EVLNLYYSYAGWELOSY 614 GTKISVLPQELRNLRMLKHLDLQRTQFLQTIPRDAICWLSKL-EVLNLYYSYAGWELQSY 649 GTKISVLPRELGNLRMLKHLDLQRTQFLQTISRDAICWLSKLGESIGSCNSDAGWELQSD 616 GTKISVLPQELGNLRKLKHLDLQRTQFLQTIPRDAICWLSKL-EVLNLYYSYAGWELQSF 648

GEDEEE-ELGEADLEHLENLTTLGITVLSLESLKTLYEFDVLHKCIQHLHVEECNGLPHF 673 GEDEEE-ELGFADLEHLENLTTLGITVLSLESIKTLYEEDVLHKCIOHLHVEECNGLPHF 708 GENEKKKTLGFADLEHLENLTTLGMTVLSLESLKTLYEFDALHKCIOHLHVEECNGLPHF 676 GEDEAE-ELGEADLEYLENLTTLGITVLSLETLKTLFEFGALHKHIQHLHVEECNELLYF 707

DLSSLSNHGGNIRRLSIKSCNDLEYLITPTDVD--WLPSLEVLTVHSLHKLSRVWGNSVS 731 DLSSLSNHGGNIRRLSIKSCNDLEYLITPTDVD--WLPSLEVLTVHSLHKLSRVWGNSVS 766 DLSSLSNHGGNLRRLSIKSCHDLEYLVTPTDVD--WLPSLEVLTVHSLHKLSRVWGNSVS 734 NLPSLTNHGRNLRRLSIKSCHDLEYLVTPADEENDWLPSLEVLTLHSLHNLTRVWGNSVS 767

QESLRNIRCINISHCHKLKNVSWAQQLPKLETIDLEDCRELEELISDLESPSIEDLVLFP 791 QESLRNIRCINISHCHKLKNVSWAQQLPKLETIDLFDCRELEELISDHESPSIEDLVLFP 826 QESLRNIRCMNISHCHKLKNVSWAQQLPKLETIDLFDCRELEELMSDHESPSIEDLVLEP 794 QDCLRNIRCINISHCNKLKNVSWVQKLPKLEVIELEDCREIEELISEHESPSVEDPTLFP 827

GLKTLSIRDLPELSSILPSRESFQKLETLVIINCPKVKKLPE--------------- 833 GLKTLSIRDLPELSSILPSRFSFOKLETLVI INCPKVKKLPEOER-VQPNLPAVYCDEKW 885

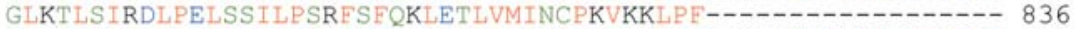
SLKTLRTRDLPELNSILPSRESEQKVETLVITNCPRVKKLPEQERRTQMNLPTVYCEEKW 887

Figure 1 - Alignment of the amino acid sequences of BI-16/RPS2, Lc201/RPS2 and RPS2 from Arabidopsis thaliana (ATU14158) and B117 from Brassica oleracea (AF180357). 


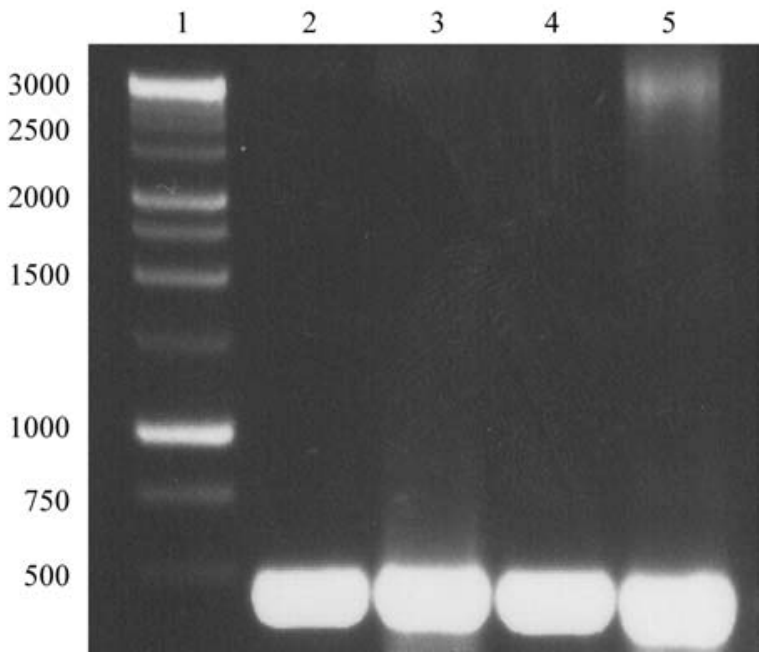

Figure 2 - RT-PCR analysis of mRNA isolated from leaves $24 \mathrm{~h}$ after inoculation. Lane 1 - 1 kb DNA ladder (Promega), lanes 2 and 3 - positive control with genomic DNA from BI-16 and Lc201, respectively; lanes 4 and 5 - PCR with cDNA from BI-16 and Lc201, respectively.

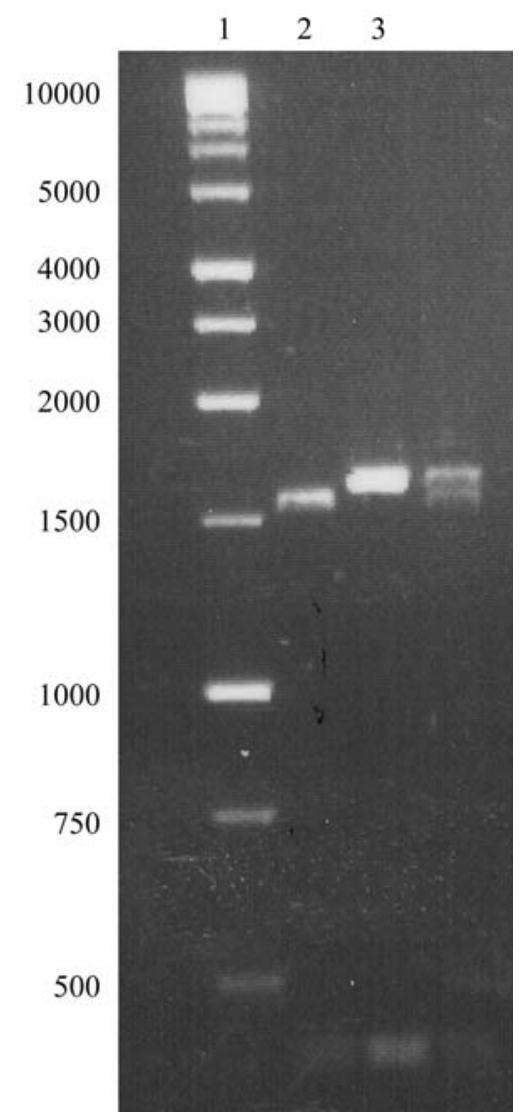

Figure 3 - Restriction patterns for BI-16, Lc201 and F1, digested with Xba I. Lane 1 - 1kb DNA ladder (Promega); lane 2- BI-16 ; lane 3 - Lc201.

Most of the resistance genes characterized so far belong to families of tightly linked genes. The Rpl locus of maize (Sun et al., 2000), I2 of tomato (Simons et al., 1998), and Dm3 of lettuce (Shen et al., 1998) span a large region of the genome. Over 24 candidate genes covering $3.5 \mathrm{Mb}$ of the Dm3 locus in lettuce (Shen et al., 2002) have been characterized. The occurrence of gene clusters may provide genetic variation from which new resistance genes evolve. Clusters may also confer specificity to a wide range of pathogens. Mechanisms such as duplication, unequal crossing-over, gene conversion, and transposable elements have been proposed to contribute to recombination between clustered genes (Hulbert et al., 2001). The Pto locus has four homologs that map to a syntenic region in tomato, potato and pepper. Fen gene homologs isolated from two species of tomato showed $97 \%$ and $95 \%$ nucleotide identity, but only the Fen gene was effective in recognizing fenthion (Riely and Martin, 2001).

The BI-16/RPS2 homolog contained an open reading frame with a predicted frame shift. However, the partial BI-16/RPS2 cDNA sequence aligned at this very region. Frame shifts and stop codons are common in homologs (Vicente and King, 2001). Despite the presence of frame shifts and retroelement insertions in the RPP5 gene family, these genes may still be functional (Nöel et al., 1999). The homologs described here may also be functional in other cultivars or species. In addition, a cluster of Arabidopsis ESTs clones with high homology to our cDNA sequences has been mapped to chomosome 4 and linked to the RPS2 locus. Definitive proof that these sequences correspond to a resistance gene requires transgenic expression (Shen et al., 1998)

\section{Acknowledgments}

The authors thank Giovana G. C. Silva for help with the DNA sequencing. This work was supported by the São Paulo State Funding Agency (FAPESP) in the form of a fellowship to C.C.M. and through two grants (nos. 99/00800-8 and 00/09059-8).

\section{References}

Aarts MG, Hekkert BL, Holub EB, Beynon JL, Stiekema WJ and Pereira A (1998) Identification of R-gene homologous DNA fragments genetically linked to disease resistance loci in Arabidopsis thaliana. Mol Plant-Microbe Interact 11:251258.

Altschul SF, Madden TL, Schaffer AA, Zhang Z, Miller W and Lipman Dj (1997) Gapped BLAST and PSI-BLAST: a new generation of protein database search programs. Nucleic Acids Res 25:3389-3402.

Axtell MJ, McNellis TW, Mudgett MB, Hsu CS and Staskawicz BJ (2001) Mutational analysis of the Arabidopsis RPS2 disease resistance gene and corresponding Pseudomonas syringae avrRpt 2 avirulence gene. Mol Plant-Microbe Interact 14:181-188.

Banerjee D, Zhang X and Bent AF (2001) The leucine-rich repeat domain can determine effective interaction between RPS2 and other host factors in Arabidopsis RPS2-mediated disease resistance. Genetics 158:439-450. 
Bent AF, Kunkel BN, Dahlbeck D, Brown KL, Schmidt R, Giraudat J, Leung J. and Staskawicz BJ (1994) RPS2 of Arabidopsis thaliana: A leucine-rich repeat class of plant disease resistance. Science 265:1856-1860.

Bergelson J, Kreitman M, Stahl EA and Tian D (2001) Evolutionary dynamics of plant R-genes. Science 292:2281-2285.

Caicedo AL, Schaal BA and Kunkel BN (1999) Diversity and molecular evolution of the RPS2 resistance gene in Arabidopsis thaliana. Proc Natl Acad Sci USA 96:302-306.

Camargo LEA, Williams PH and Osborn TC (1995) Mapping of quantitative trait loci controlling resistance of Brassica oleracea to Xanthomonas campestris pv. campestris in the field and greenhouse. Phytopathology 85:1296-1300.

Collins NC, Webb CA, Seah S, Ellis JG, Hulbert SH and Pryor A (1998) The isolation and mapping of disease resistance gene analogs in maize. Mol Plant-Microbe Interact 11:968-978.

Dangl JL and Jones JD (2001) Plant pathogens and integrated defense responses to infection. Nature 411:826-833.

Hulbert SH, Webb CA, Smith SM and Sun Q (2001) Resistance gene complexes: evolution and utilization. Annu Rev Phytopathol 39:285-312.

Jones, JDG (2001) Putting knowledge of plant disease resistance genes to work. Curr Opin Plant Biol 4:281-287.

Leister D, Kurth J, Laurie DA, Yano M, Sasaki T, Devos K, Graner A and Schulze-Lefert P (1998) Rapid reorganization of resistance gene homologues in cereal genomes. Proc Natl Acad Sci USA 95:370-375.

Malvas CC, Coêlho RMS and Camargo LEA (1999) Identificação de genes de resistência a podridão negra em Brassica oleracea por meio de genotipagem seletiva. Fitopatol Bras 24:143-148.

Martin GB (1999) Functional analysis of plant disease resistance genes and their downstream effectors. Curr Opin Plant Biol 2:273-279.

Melotto M and Kelly JD (2001) Fine mapping of the Co-4 locus of common bean reveals a resistance gene candidate, COK-4, that encodes for a protein kinase. Theor Appl Genet 103: 508-517.

Mindrinos M, Katagiri F, Yu GL and Aususbel FM (1994) The $A$. thaliana disease resistance gene RPS2 encodes a protein containing a nucleotide-binding site and leucine-rich repeats. Cell 78:1089-1099.

Nöel L, Moores TL, van der Biezen EA, Parniske M, Daniels MJ, Parker JE and Jones JDG. (1999) Pronounced intraspecific haplotype divergence at the RPP5 complex disease resistance locus of Arabidopsis. Plant cell 11:2099-2111.

Riely BK and Martin GB (2001) Ancient origin of pathogen recognition specificity conferred by the tomato disease resistance gene Pto. Proc Natl Acad Sci USA 98:2059-2064.

Sambrook J, Fritsch EF and Maniatis T (1989) Molecular Cloning: A Laboratory Manual. 2nd ed Cold Spring Harbor Laboratory, Cold Spring Harbor, NY, 236 pp.

Schaal BA and Olsen, KM (2000) Gene genealogies and population variation in plants. Proc. Natl. Acad. Science 97:70247029.

Shen KA, Chin DB, Arroyo-Garcia R, Ochoa OE, Lavelle DO, Wroblewski T, Meyers, BC and Michelmore RW (2002) $D m 3$ is one member of a large constitutively expressed family of nucleotide binding site-leucine-rich repeat encoding genes. Mol Plant-Microbe Interact 15:251-261.

Shen KA, Meyers BC, Islam-Faridi MN, Chin DB, Stelly DM and Michelmore RW (1998) Resistance gene candidates identified using PCR with degenerate primers map to resistance gene clusters in lettuce. Mol Plant-Microbe Interact 11:815-823.

Simons G, Groenendijk J, Wijbrand J, Reijans M, Groenen J, Diergaarde P, Van der Lee T, Bleeker M, Onstenk J, Both M, Haring M, Mes J, Cornelissen B, Zabeau M and Vos P (1998) Dissection of the Fusarium I2 gene cluster in tomato reveals six homologs and one active gene copy. Plant Cell 10:1055-1068.

Speulman E, Bouchez D, Holub EB and Beynon JL (1998) Disease resistance gene homologs correlate with disease resistance loci of Arabidopsis thaliana. Plant J 14:467-474.

Staskawicz BJ (2001) Genetics of plant-pathogen interactions specifying plant disease resistance. Plant Physiol 125:73-76.

Sun Q, Collins NC, Ayliffe M, Smith SM and Drake J (2000) Recombination between paralogs at the rpl rust resistance locus in maize. Genetics 158:423-438.

Vicente JG and King GJ (2001) Characterization of disease resistance gene-like sequences in Brassica oleracea L. Theor Appl Genet 102: 555-563.

Williams PH and Hill CB (1986) Rapid-cycling populations of Brassica. Science 232:1385-1389.

Wroblewski T, Coulibaly S, Sadowsk J and Quiros CF (2000) Variation and phylogenetic utility of the Arabidopsis thaliana RPS2 homolog in various species of the tribe Brassiceae. Mol Phylogenetics Evol 16:440-448.

Editor: Márcio de Castro Silva Filho 